Article

\title{
High Production of Chitinolytic Activity in Halophilic Conditions by a New Marine Strain of Clonostachys rosea
}

\author{
Marcella Pasqualetti ${ }^{1,2}$, Paolo Barghini ${ }^{1}$, Valeria Giovannini ${ }^{1}$ and Massimiliano Fenice ${ }^{1,3, *(D)}$ \\ 1 Dipartimento di Scienze Ecologiche e Biologiche, University of Tuscia, 01100 Viterbo, Italy; \\ mpasqual@unitus.it (M.P.); barghini@unitus.it (P.B.); v.giovannini@unitus.it (V.G.) \\ 2 Laboratorio di Ecologia dei Funghi Marini, CoNISMa, University of Tuscia, 01100 Viterbo, Italy \\ 3 Laboratorio di Microbiologia Marina Applicata, CoNISMa, University of Tuscia, 01100 Viterbo, Italy \\ * Correspondence: fenice@unitus.it; Tel.: +39-0761-357-318
}

Received: 18 April 2019; Accepted: 15 May 2019; Published: 16 May 2019

check for check for
updates

\begin{abstract}
Twenty-eight fungal strains have been isolated from different natural marine substrates and plate screened for their production of chitinolytic activity. The two apparent best producers, Trichoderma lixii IG127 and Clonostachys rosea IG119, were screened in shaken cultures in media containing $1 \%$ colloidal chitin, $1 \%$ yeast nitrogen base and $38 \% \mathrm{NaCl}$, for their ability to produce chitinolytic enzymes under halophilic conditions. In addition, they were tested for optimal growth conditions with respect to $\mathrm{pH}$, salinity and temperature. The Trichoderma strain appeared to be a slight halotolerant fungus, while C. rosea IG119 clearly showed to be a halophilic marine fungus, its optimal growth conditions being very coherent for life in the marine environment (i.e., pH 8.0, salinity $38 \%$ o). Due to its high and relatively fast activity (258 U/L after $192 \mathrm{~h}$ of growth) accompanied by its halophilic behaviour (growth from 0 to 160\% of salinity), C. rosea was selected for further studies. In view of possible industrial applications, its medium for chitinolytic enzyme production was optimized by Response Surface Methodology using 1\% colloidal chitin and different concentrations of corn step liquor and yeast nitrogen base (0-0.5\%). Time course of growth under optimized condition showed that maximum activity (394 U/L) was recorded after $120 \mathrm{~h}$ on medium containing Corn Steep Liquor $0.47 \%$ and Yeast Nitrogen Base $0.37 \%$. Maximum of productivity ( $3.3 \mathrm{U} / \mathrm{Lh}$ ) was recorded at the same incubation time. This was the first study that demonstrated high chitinolytic activity in a marine strain of C. rosea.
\end{abstract}

Keywords: marine fungi; halophiles; chitinolytic enzymes; high producer; Clonostachys rosea; screening; Response Surface Methodology

\section{Introduction}

The various and multiform marine environments are sources of chemical and biological diversity of paramount importance and an inexhaustible resource of unexploited and/or unknown microorganisms. Hence, oceans and seas represent a huge reserve of new substances with potential applications in feed and food, fine chemicals, pharmaceutical and enzyme industries [1-3]. The industrial and commercial value of enzymes increased in the past two decades in traditional fields such as food and detergent industries, but also in different areas, where it is still growing, particularly in textile and leather industries, environment depollution, medical applications, biotechnology, bioenergy, biosensors and so on. A recent assessment (2017) has valued the global enzymes market at more than $\$ 7000$ million, and the business is estimated to exceed $\$ 10,000$ million in 2024 [4].

The search of new or improved enzymes is a very worthwhile business for which the marine environment should not be overlooked since there is a large interest in recruiting microbial enzymes for 
the development of environmentally-friendly industrial applications [1,5]. Interesting new biocatalysts with peculiar properties, such as high salt tolerance, hyperthermostability, piezophilicity and cold adaptivity, can be obtained by marine enzyme biotechnology [6]. Actually, the knowledge of enzymes having optimal activities at uncommon values of salt concentration, $\mathrm{pH}$ and temperature is useful; in addition, a marine-derived enzyme may show novel and useful chemical and stereochemical properties [2].

Nevertheless, the exploitation of marine environments for new enzyme producers is still scarce if compared with other environments [1,6]. Only a rather limited number of works have been carried out to screen in detail the marine microorganisms' capacity to produce extracellular enzymes and end even less investigated marine fungi $[1,7,8]$.

On the whole, the most commonly studied enzymes are those involved in the hydrolysis of biopolymers. Among them, chitinolytic enzymes, even though rather widely studied, still need investigation for their wide pattern of industrial and environmental applications where new and suitable sources of these bio-catalysts are requested [9].

Chitin is one of the most abundant natural polysaccharides; it is an important source of carbon and nitrogen for marine organisms and its turnover in the aquatic biosphere is quite high. It has been estimated that more than $10^{11}$ metric tons of this polysaccharide are produced annually and the oceans represent a huge resource of chitin that should be transformed in other biological materials to avoid carbon and nitrogen depletion in these environments. Actually, marine sediments contain only trace of chitin, the degradation of which is a main step in the cycling of nutrients in the oceans that is traditionally attributed mainly to bacteria [10-12]. In addition, fungi can contribute substantially to chitin degradation and recycle, particularly in some marine environments such as sediments and estuaries [10,13].

Chitin hydrolysis is carried out by a series of chitin-degrading enzymes, the classification of which is quite ambiguous and confusing $[9,14]$. Anyway, current classification, given by the Enzyme Commission (EC), only considers two classes of enzymes: Chitinase, (EC 3.2.1.14) performing "random hydrolysis of $N$-acetyl- $\beta$-D-glucosaminide (1-4)- $\beta$-linkages in chitin and chitodextrins"; and $\beta-N$-acetylhexosaminidase (EC 3.2.1.52) that "releases N-Acetyl-D-hexosamine residues, at the non-reducing terminal, from chitin and chitodextrins".

Nonetheless, numerous authors still use old classifications and use different "names" for the various chitinolytic activities. The enzymes performing a random hydrolysis inside the polysaccharide, producing shorter fragments, are often defined as "endo-chitinases", while those having an external activity are defined as "exo-chitinases". The enzymes acting only on chitobiose are called "chitobiases", while those releasing chitobiose from chitin or chitodextrins are named "chitobiosidases" [9,14-17].

While some innovative applications have been tested at the laboratory level [18,19], these enzymes traditionally are used in the hydrolysis of chitin and chitin-containing materials, production of chitin derivatives, protoplast formation and biocontrol of pathogenic organisms [9]. However, some of the mentioned environmental applications (i.e., on-field control of pathogens or degradation of chitin-rich wastes), can be sturdily limited by adverse conditions, in particular low temperature and salinity, which could affect the microbial activity. It has been demonstrated that psychrotolerant microorganisms, producing high levels of cold-active chitinolytic enzymes, can be important to replace mesophilic strains in case of applications at low temperature: Here the search for new chitinolytic organisms is of great applied interest [9,20-22]. By contrast, the search for microorganisms able to produce high levels of chitinolytic enzymes in halophilic conditions is rather scarce and mainly regards bacteria; marine fungi have been somehow overlooked and chitinase production has only been studied in a few species $[23,24]$. The availability of marine chitinolytic microorganisms and/or enzymes, able to work in halophilic conditions and in broad ranges of other parameters such as $\mathrm{pH}$, would be useful in various fields. For example, they could find applications in the production of high-value chitin-derivatives (i.e., chito-oligosaccharides) or degradation of salty chitin-rich materials (i.e., residues from the crab or 
shrimp industries). They could be also used in food technology to control spoiling organisms where high concentration of $\mathrm{NaCl}$ is present [25-27].

In this study, we report on a screening carried out on 28 fungal strains (obtained from various substrates collected in the East Sector of the Tyrrhenian Sea) in order to test their potential to produce high level of extracellular chitinolytic enzymes activity. The activity of most promising strains was verified in shaken cultures and they were investigated for optimal growth conditions with respect to $\mathrm{pH}$, temperature and salinity. Among them, the ascomycete Clonostachys rosea IG119, was investigated in details for its high production in view of possible industrials applications; optimization of its culture media to maximize the enzyme production was carried out by Response Surface Methodology (RSM).

\section{Results and Discussion}

\subsection{Plate Screening for Chitinolytic Enzyme Producers}

The results of the preliminary plate screening showed that 11 strains out of $28(39 \%)$ were able to degrade chitin (Table 1). Among them we recorded species of Chaetomidium, Chaetomium, Clonostachys, Pleospora, Stachybotrys and Trichoderma. Some of them revealed a rather high activity, but the highest activity was recorded for Trichoderma lixii IG127 and Clonostachys rosea IG119, which showed also best growth (Figure 1A). Various Trichoderma species are well known for their high production of hydrolases including high levels of chitinase. Among them it is important to mention T. resei for its cellulase production and T. harzianum for its very significant chitinolytic activity [28]. T. lixii is not known for the production of these enzymes. Nevertheless, this species was recently recognised within the T. harzianum complex [29] and its production of chitinolytic enzymes recorded in our study was not unexpected. Various species of Trichoderma had been recognised as derived from marine environments also in recent studies $[30,31]$.

Table 1. Taxonomical affiliation and chitinolytic enzyme activity of the various fungal strains isolated from different marine substrates.

\begin{tabular}{|c|c|c|c|}
\hline Strain & Taxa & Substrate & Activity \\
\hline IG132 & Alternaria chlamydospora & $\mathrm{DD}$ & - \\
\hline IG135 & Arthrinium sp. & $\mathrm{SC}$ & - \\
\hline IG133 & Aspergillus flavus & SC & +++ \\
\hline IG105 & Aspergillus insuetus & $\mathrm{PO}$ & ng \\
\hline IG136 & Aspergillus spelaeus & SC & ng \\
\hline IG125 & Aspergillus versicolor & DD & - \\
\hline IG118 & Cephalotrichum gorgonifer & $\mathrm{PO}$ & - \\
\hline IG129 & Chaetomidium fimeti & DD & ++ \\
\hline IG134 & Chaetomidium fimeti & SC & + \\
\hline IG110 & Chaetomium sp. 1 & $\mathrm{PO}$ & ++ \\
\hline IG107 & Chaetomium sp. 2 & $\mathrm{PO}$ & +++ \\
\hline IG124 & Cladosporium sp. 1 & DD & - \\
\hline IG101 & Cladosporium sp. 2 & $\mathrm{PO}$ & - \\
\hline IG123 & Clonostachys rosea & $\mathrm{PO}$ & + \\
\hline IG117 & Clonostachys rosea & $\mathrm{PO}$ & ++ \\
\hline IG119 & Clonostachys rosea & $\mathrm{PO}$ & ++++ \\
\hline IG120 & Fusarium sp. & $\mathrm{PO}$ & ng \\
\hline IG100 & Mariannaea sp. & $\mathrm{PO}$ & ng \\
\hline IG121 & Microascus brevicaulis & $\mathrm{PO}$ & ng \\
\hline IG103 & Penicillium sp. & $\mathrm{PO}$ & - \\
\hline IG113 & Pleospora sp. & $\mathrm{PO}$ & ng \\
\hline IG122 & Scopulariopsis sp. & $\mathrm{PO}$ & - \\
\hline IG126 & Stachybotrys chlorohalonatus & DD & +++ \\
\hline IG127 & Trichoderma lixii & DD & ++++ \\
\hline IG131 & Micelia sterilia 1 & DD & + \\
\hline IG114 & Micelia sterilia 2 & $\mathrm{PO}$ & ng \\
\hline IG108 & Micelia sterilia 3 & $\mathrm{PO}$ & ng \\
\hline IG115 & Micelia sterilia 4 & $\mathrm{PO}$ & ng \\
\hline
\end{tabular}

Legend: $\mathrm{DD}=$ Dictyota dichotoma, $\mathrm{PO}=$ Posidonia oceanica, $\mathrm{SC}=$ Sphaerococcus coronopifolius. ng = no growth. Activity was arbitrary scored from "- " no activity to " ++++ " highest activity. 


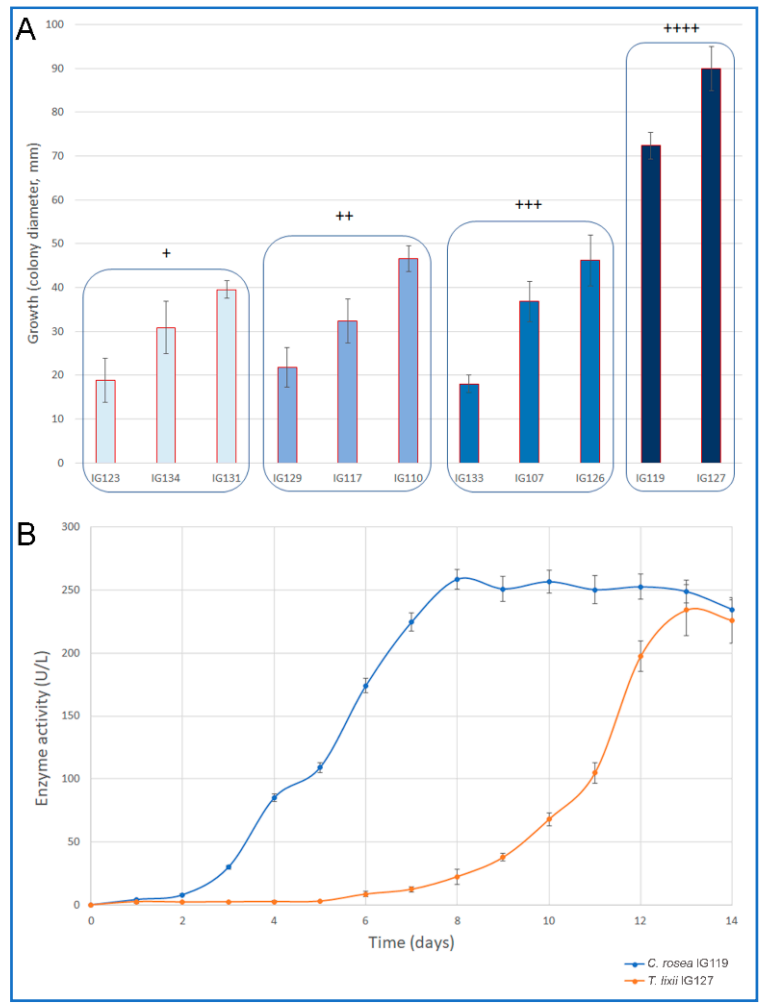

Figure 1. (A) growth of marine fungal isolates on the media used for the detection of chitinolytic activity. The isolates have been grouped on the base of their enzyme activity (scores from " +" to "+++".

(B) Time course of chitinolytic enzyme production of Trichoderma lixii IG127 and Clonostachys rosea IG119 on the medium used for the secondary screening.

Additionally, C. rosea is known for its production of chitinolytic enzymes [32,33]; as for various Trichoderma strains, it is used as a biocontrol agent against phyto-pathogenic fungi due to its mycoparasitic action, which is mainly due to the production of this class of enzymes [33]. The mycoparasitic action of $C$. rosea is so powerful that this species has been defined as the "the best known destructive mycoparasite" [28]. However, only one marine-derived strain of Clonostachys rosea has been reported [34], but its chitinolytic or mycoparasitic activities have not been investigated yet.

\subsection{Secondary Screening for Chitinolytic Enzymes}

The secondary screening in shaken cultures was carried out only for the two selected strains, under non-optimized halophilic condition. Figure 1B shows the time course of the enzyme production for the two strains. The maximum production by T. lixii IG127, even if rather good, was strongly delayed (238 $\mathrm{U} / \mathrm{L}$ after 12 days of incubation) since the fungus showed a long lag phase (5 days). By contrast, C. rosea IG119 started its production only after two days of incubation; its maximum activity was recorded at day $8(258 \mathrm{U} / \mathrm{L})$ to remain quite stable thereafter. The two fungi were selected for further studies. In any case, the maximum activity obtained by the two strains in these non-optimized conditions, even delayed, was at the same level of that recorded for well-known chitinolytic fungi such as Trichoderma harzianum P1 and Lecanicillium muscarium CFEE 5005 cultivated using similar growth medium, but not in halophilic conditions [20].

\subsection{Optimal Growth Conditions with Respect to Temperature, $\mathrm{pH}$ and Salinity}

The selected strains were grown on media with different $\mathrm{pH}$ (range 3.5-10.5), temperature (range $5-40{ }^{\circ} \mathrm{C}$ ) and salinity (range $0-180 \%$ o) in order to understand their possible adaptation to marine environment (Figure 2). 


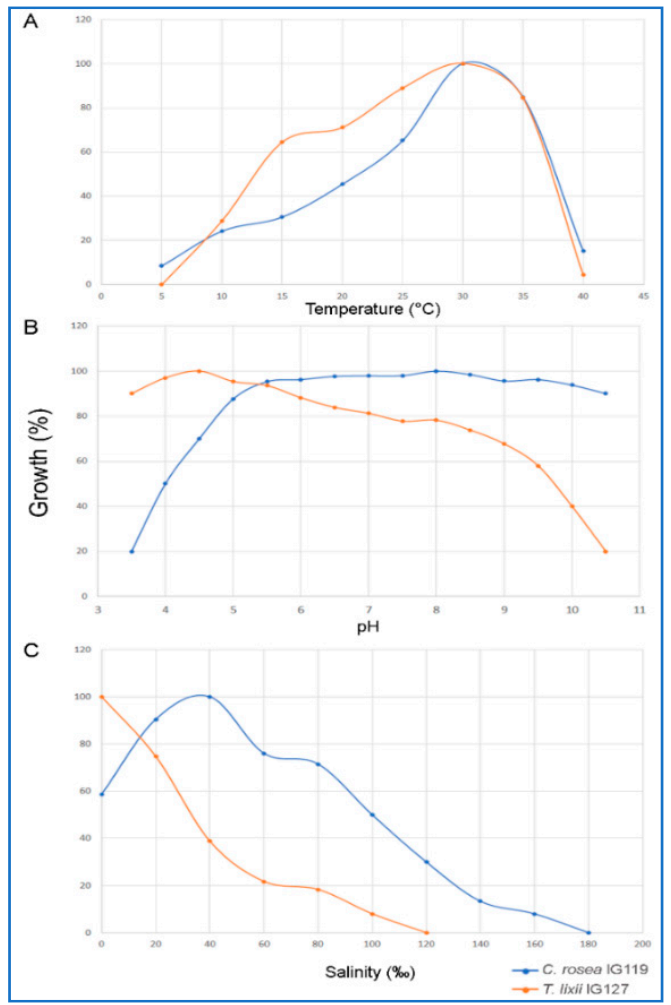

Figure 2. Growth of Trichoderma lixii IG127 and Clonostachys rosea IG119 in agar media at different values of temperature (A), $\mathrm{pH}(\mathbf{B})$ and salinity $(\mathbf{C})$. Data are reported as percentage of maximum growth.

T. lixii IG127 showed to be a mesophilic-psychrotolerant fungus being able to growth in the range $5-40{ }^{\circ} \mathrm{C}$ with optimum at $30{ }^{\circ} \mathrm{C}$ (Figure $2 \mathrm{~A}$ ). It was also able to grow in a rather wide range of $\mathrm{pH}$ (3.5-10.5) with optimum at $4.5 \mathrm{pH}$ (Figure 2B). Its growth with respect to salinity was typical of a slight halotolerant microorganism. Its optimal growth was recorded at about $0 \%$ o of marine salt (growth range $0-100 \%$ of salinity). However, it is worth noting that its growth rate rapidly dropped with the increase of $\mathrm{NaCl}$ concentration; at the sea salinity (38-40\%o) growth was already $60 \%$ lower than that recorded at $0 \%$; no growth was recorded at $120 \%$ ond above (Figure $2 \mathrm{C}$ ).

For these reasons this strain should not be considered as a marine fungus, but a terrestrial fungus somehow adapted to marine environmental conditions. This would justify the long lag phase recorded in the medium used for the secondary screening, which contained $38 \%$ of marine salt.

By contrast, C. rosea IG119 characteristics suggested that this strain could be considered as a marine fungus. The results obtained evidenced that its optimal conditions for growth appeared to be coherent with the typical environmental parameters of the sea (Figure 2). Best growth was recorded at $8.0 \mathrm{pH}$ (range 3.5-10.5 pH); however, this optimal value must be considered quite virtual since this fungus showed optimal or sub-optimal growth in a very broad range of $\mathrm{pH}$ (5.5-9.5) with non-statistically significant variations of its growth rate. Optimal growth in a wide $\mathrm{pH}$ range is a known characteristic of this species [28]. In any case, its adaptation to salinity was a decisive point for its classification as a moderate-halophilic marine fungus. Its optimal growth was recorded at $38-40 \%$ of salinity and a certain euryhalinism was verified since its range of salinity for growth was $0-160 \%$. The capacity of growth also with minimal concentrations of $\mathrm{NaCl}$ was also a worth noting characteristics; in absence of $\mathrm{NaCl}$ its growth rate was still $40 \%$ of that recorded at the optimum. These features were quite unexpected, since it was observed that this species was not able to growth in media containing $50 \%$ o of $\mathrm{NaCl}$ [28]. The psychrotolerant behaviour of strain IG119 was less evident since it was not able to grow at $5{ }^{\circ} \mathrm{C}$; however, its eurythermism was somehow very convincing since rather high growth rates were recorded between 15 and $35^{\circ} \mathrm{C}$. 
Since this work was aimed to find new high producers of chitinolytic enzymes under halophilic conditions, only C. rosea IG119 was selected for the optimization of the growth medium by RSM.

\subsection{Optimization of the Cultural Medium by Response Surface Methodology}

RSM is one of the most efficient methods to get a performing experimental design. This method is widely used to optimize process parameters in fermentation technology. Additionally, it has also been used to optimize chitinases production by fungi [14,35].

In this work RSM was used to optimise the culture medium for best production of chitinolytic activity by C. rosea IG119 in view of a possible industrial application where the growth medium composition and its cost have a paramount importance. An industrial growth medium must be as cheap as possible since $20-30 \%$ or more of the cost of the final product, obtained by microbial bioprocesses (fermentations), depends on its composition. Moreover, it must permit the maximization of the microbial production, not only in terms of maximum production, but also with respect to yield and/or productivity. In our case the medium used in the preliminary experiments contained, chitin apart, Yeast Nitrogen Base (YNB) that is a very good nitrogen source (essentially a mix of different vitamins, other nitrogen sources and mineral salts) to be used at the laboratory level. However, it is too expensive for industrial applications. By contrast, Corn Steep Liquor (CSL), being a by-product of the corn processing industry, is quite cheap and often used as a nitrogen supplement in industrial fermentations. Due to its very composite formulation rich in carbohydrates, amino acids, polypeptides, fatty acids, other organic compounds and inorganic ions, it is considered a valid bio-stimulant additive for bioprocesses [36-38]. Thus, RSM optimization was carried out using an experimental model considering combinations of different amounts of these two substrates according to a D-optimal design, as suggested by the software.

Model performance was definitely good. Data were best fitted by a polynomial quadratic equation, as it can be inferred by the good agreement of experimental data with those estimated by the model. Table 2 shows the regression results of the experimental data of the D-optimal model, which revealed that the effect of CSL was more significant than that of YNB on both production and productivity of the chitinolytic enzymes by C. rosea.

Table 2. Model coefficients estimated by multiple linear regression (significance of regression coefficients).

\begin{tabular}{|c|c|c|c|c|c|c|}
\hline \multirow[b]{2}{*}{ Coefficient } & \multicolumn{3}{|c|}{ Production (U/L) } & \multicolumn{3}{|c|}{ Productivity (U/Lh) } \\
\hline & RC & SE & $\mathbf{P}$ & RC & SE & $\mathbf{P}$ \\
\hline Constant & 3.5158 & 0.1112 & $1.10 \times 10^{-13}$ & 3.4515 & 0.1224 & $4.7937 \times 10^{-13}$ \\
\hline CSL & 0.8666 & 0.0688 & $1.17 \times 10^{-8}$ & 0.9656 & 0.0758 & $1.0124 \times 10^{-8}$ \\
\hline YNB & 0.6908 & 0.0688 & $1.72 \times 10^{-7}$ & 0.5917 & 0.0758 & $2.9116 \times 10^{-6}$ \\
\hline $\mathrm{CSL}{ }^{*} \mathrm{CSL}$ & -0.4204 & 0.1139 & $2.71 \times 10^{-3}$ & -0.1911 & 0.1254 & $1.5150 \times 10^{-1}$ \\
\hline YNB*YNB & -0.5110 & 0.1139 & $6.13 \times 10^{-4}$ & -0.5601 & 0.1254 & $6.3504 \times 10^{-4}$ \\
\hline $\mathrm{CSL}^{*} \mathrm{YNB}$ & -0.2251 & 0.0843 & $1.92 \times 10^{-2}$ & -0.0978 & 0.0928 & $3.1117 \times 10^{-1}$ \\
\hline \multicolumn{7}{|c|}{ ANOVA table (Modde 5) } \\
\hline F value & 60.7442 & \multicolumn{2}{|c|}{$P=0.000$} & 49.656 & \multicolumn{2}{|c|}{$\mathrm{P}=0.000$} \\
\hline $\mathrm{Q}^{2}$ & 0.92 & & & 0.895 & & \\
\hline $\mathrm{R}^{2}$ & 0.959 & & & 0.95 & & \\
\hline $\mathrm{R}^{2}$ adjusted & 0.943 & & & 0.931 & & \\
\hline
\end{tabular}

Legend. $\mathrm{RC}=$ regression coefficient, $\mathrm{SE}=$ standard error, $\mathrm{P}=p$ value.

In addition, the model revealed high reliability and good statistical performance. For both the analysed responses (production and productivity), the probability for the regression was significant at $\geq 95 \%$ and there was no lack of fit.

As for the chitinolytic enzyme production and productivity, the correlation coefficients $\left(R^{2}\right)$, indicating the fraction of response variation explained by the model, were very high (0.959 and 0.95 , respectively). This means that the statistical model can explain 95.9 and $95.0 \%$ of the response 
variability. Moreover, $\mathrm{Q}^{2}$ values, indicating the fraction of response variation that can be predicted by the model, were rather good (0.92 and 0.895, respectively). Finally, the results of the ANOVA analysis run by the Modde 5 software showed significant F-values (60.74 and 49.66, respectively, $\mathrm{P}=0.000$ ), indicating that the model terms were quite significant (Table 2).

The RSM permitted taking into account the effects of the two nitrogen sources as used alone (Figure 3A). YNB appeared to be somehow inhibiting when its concentration exceeded $0.4 \%$, while the enzyme activity seemed to be directly proportional to CSL concentration, even if the trend showed that a plateau could be reached rapidly over $0.5 \%$. However, best enzyme production was obtained by a synergistic combination of the two substances. Model indicates that highest production (circa $360 \mathrm{U} / \mathrm{L}$ ) could be obtained at about $0.35 \%$ of YNB and $0.45 \%$ CSL (Figure 3B). As for productivity, a maximum of circa $3 \mathrm{U} / \mathrm{Lh}$ was predicted at the same concentrations of the two nitrogen sources (figure not shown). However, the best result obtained experimentally was $363.8 \mathrm{U} / \mathrm{L}$ using $0.5 \%$ of YNB and $0.5 \%$ CSL (Experiment $\mathrm{N}^{\circ} 4$ ) after $120 \mathrm{~h}$ of incubation. By running the software "optimizer" function, the model suggested that optimal conditions for the enzyme production were CSL $0.47 \%$, YNB $0.37 \%$ in order to expect a maximum activity of $365.3 \mathrm{U} / \mathrm{L}$. The experimental validation of these expected optimal conditions, showed that actual maximum production and productivity were definitely higher than those predicted (394 U/L and $3.3 \mathrm{U} / \mathrm{Lh}$, respectively, at $120 \mathrm{~h}$ ): Activity under optimized conditions was increased circa 1.53-fold.

It is worth noting that, the maximum activity obtained with the RSM optimization was much higher (circa 53\%) than that recorded during the secondary screening. In addition, maximum production was obtained after only $120 \mathrm{~h}$ (3 days before!).

While strain IG119 chitinolytic activity seems to be quite high, the comparison with other strains of $C$. rosea is not possible since, to the best of our knowledge, there is no available study investigating the ability of the species to produce this class of enzymes in shaken cultures. While the species is known for the production of this class of enzymes, only experiments carried out in plate cultures are reported in literature, supplying just qualitative or semi-quantitative indication of the enzyme activity. By contrast, comparison with the production of other fungi, known for their high chitinolytic activity (i.e., Trichoderma spp., Penicillium spp. and Lecanicillium spp.) is possible even if not easy due to the huge amount of publications available and, in particular, for the different approaches related both to the detection and to the expression of the enzyme activity; actually, many authors use a variegated pattern of arbitrary units instead of the conventional International Unit definition.

In a previous early study, we investigated two selected strains of T. harzianum (P 1 and T 22), known for their high production of chitinolytic enzymes, in comparison with a new promising Antarctic strain of Lecanicillium muscarium (ex. Verticillium lecanii) $[9,20]$. The activity of the three strains, tested using culture conditions very similar to those reported in the present study, was comparable to that of C. rosea IG119 prior to perform RSM optimization (circa $250 \mathrm{U} / \mathrm{L}$ after $72 \mathrm{~h}$ of growth). Subsequent optimization of L. muscarium chitinolytic enzymes production in bioreactor by RSM lead to increase it activity up to circa $380 \mathrm{U} / \mathrm{L}[9,35]$. This value is similar to that obtained here in shaken flasks after RSM. Moreover, strain IG199 activity appeared much higher than that (circa 200 U/L) of another well-known strain (CECT 2413) of T. harzianum, studied in early work by De la Cruz et al. [39].

Another very promising fungus formerly investigated in our laboratory, Penicillium janthinellum P9, showed a better performance than C. rosea IG119; it enzyme activity in shaken cultures was circa $400 \mathrm{U} / \mathrm{L}$ prior to optimization (both in shaken cultures and bioreactor by RSM) that brought it up to circa $650 \mathrm{U} / \mathrm{L}[40,41]$.

Recently, a strain (ITCC-10,364.16) of Humicola grisea was investigated, during a screening of soil microorganisms, for its "notable" chitinolytic activity. However, after RSM optimization of its culture media, its activity was barely higher than $180 \mathrm{U} / \mathrm{L}$ [42].

One of the most interesting organisms investigated in recent years was the fungus Duddingtonia flagrans, which was able to produce circa 1030 U/L, after RSM optimization of its cultural medium. 
The results of the mentioned paper indicated this species as one of the most potent chitin-degrader organism among prokaryotes [43].

On the whole, even if much extensive comparison could be performed, it would be possible to affirm that the production of chitinolytic enzymes by C. rosea IG119 is high enough to consider the fungus as a promising high producer for possible applications, particularly when halophilic conditions are required.

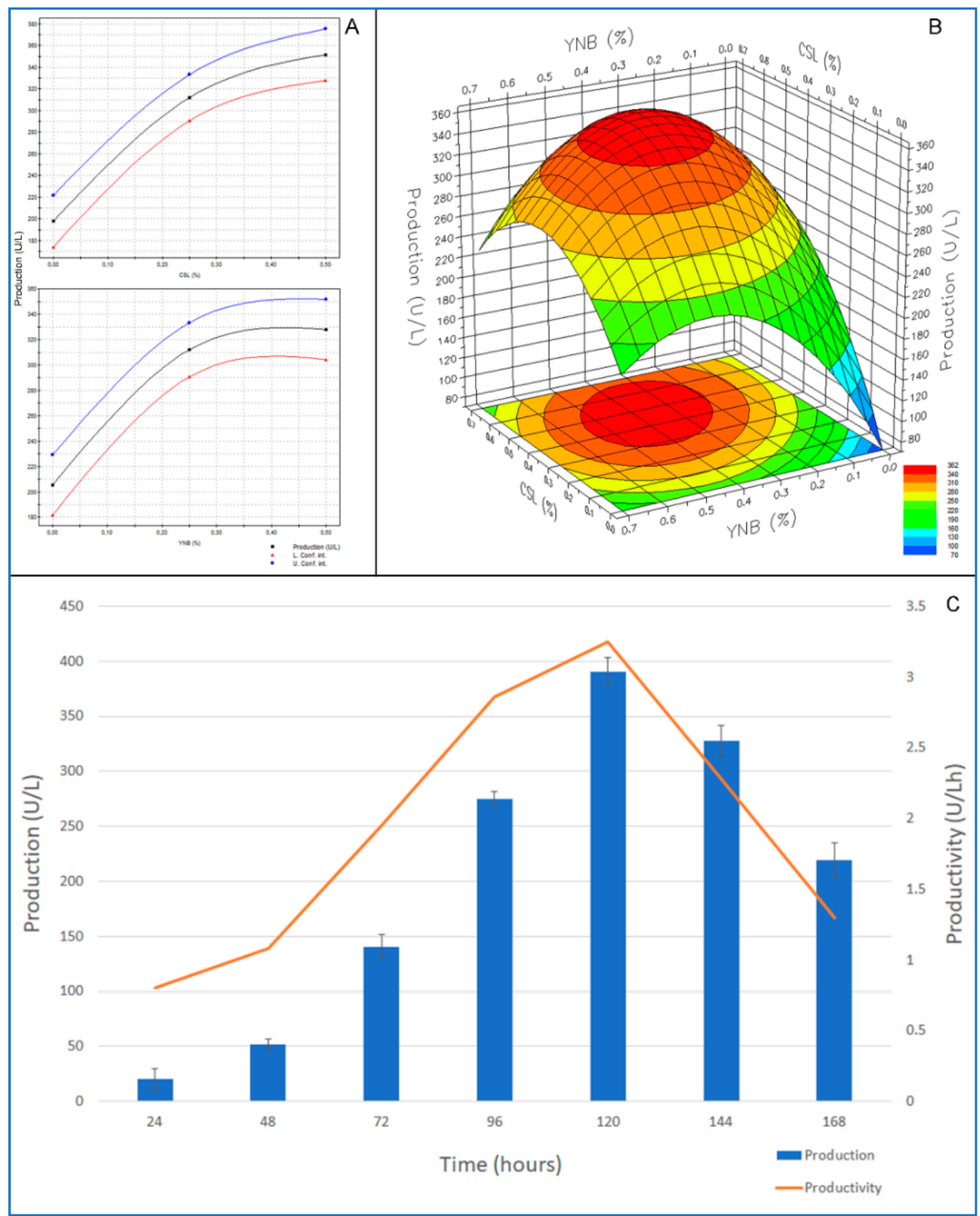

Figure 3. Single (A) and combined (B) effects of different Corn Steep Liquor (CSL) and Yeast Nitrogen Base (YNB) concentrations on the chitinolytic enzyme production by Clonostachys rosea IG119 as reported by the model. Time course of enzyme production and productivity by Clonostachys rosea IG119 cultivated on the optimized medium suggested by the Response Surface Methodology (RSM) model (C). 


\section{Materials and Methods}

\subsection{Collection of Samples and Isolation of Pure Cultures of Fungi}

Fungi were isolated from the marine phanerogam Posidonia oceanica and its epiphytic algae Dictyota dichotoma (Pheophyta) and Sphaerococcus coronopifolius (Rhodophyta) collected by scuba divers using sterile containers. Isolation of microorganisms was carried within two hours from sample retrieval as reported by [44]. Pure cultures of the fungal isolates were cryogenically maintained at $-40{ }^{\circ} \mathrm{C}$ in the culture collection of microorganisms of the "Laboratorio di Ecologia dei Funghi Marini", DEB, University of Tuscia. Strains had been revitalized and sub-cultured on Malt Extract Agar (MEA, Difco, Detroit, MI, USA) added with $38 \%$ of marine salt.

\subsection{Strain Identification}

All isolates were preliminary classified on the basis of specific taxonomic keys, according to macroscopic, microscopic and physiological features [28,45-50]. The two possible high producers, selected for further investigations, were classified also by molecular methods using the following targets: ITS region (ITS1-5.8S-ITS2) of rDNA for both strains; the actin gene for IG 127 only. Genomic DNA was extracted using ZR Fungal/Bacterial DNA MiniPrep Kit (Zymo Research, Irvine, CA, USA) according to the manufacturer's directions. The ITS region was amplified using the universal primers ITS5 and ITS4 [51] and the actin gene with ACT512F and ACT783R [52]. Taxonomic assignments were inferred by querying with the BLASTn algorithm hosted at NCBI, similarity values higher than $98 \%$ (e-value $>$ e-100) were considered reliable and the results were confirmed morphologically. The taxonomic position was inferred through phylogenetic analysis if low sequence similarity $(<98 \%)$ was obtained.

\subsection{Screening Procedure}

Semi-quantitative test for chitinolytic enzyme production (plate screening) was carried out as reported previously with slight modifications [1]. Briefly: Pre-poured MEA plates, containing 3\% of colloidal chitin and $38 \% \mathrm{NaCl}$, were inoculated with punctiform inocula, picking mycelia with sterile needles from 5-7 days cultures grown on MEA slants (at $25^{\circ} \mathrm{C}$ ). To avoid any interference from nearby colonies, only one isolate was inoculated onto each plate $(90 \mathrm{~mm}$ diameter). Activity was arbitrarily scored, based on the diameter of clarification halos on the plates, as follows: "-", no halos; "+", halos between 0.1 and $10.0 \mathrm{~mm}$; "++", halos between 10.1 and $30.0 \mathrm{~mm}$; "+++", halos between 30.1 and $60.0 \mathrm{~mm}$ and "++++", halos between 60.1 and $90.0 \mathrm{~mm}$.

Halos of chitin degradation were recorded (daily for 7 days) and measured by an image analysis software (I.A.S. ver. 008 000, Delta Sistemi, I). Secondary screening in liquid cultures was carried out for the selected strains (Trichoderma lixii IG127 and Clonostachys rosea IG119) in shaken cultures on a medium [35] containing 1\% of colloidal chitin and Yeast Nitrogen Base (YNB, Difco, Detroit, MI, USA) added with Marine salt to a final concentration of 38\%. Erlenmeyer flask (500 mL) containing $100 \mathrm{~mL}$ of medium were inoculated with circa $2.5 \mathrm{mg} / \mathrm{mL}$ dry weight of mycelium grown for 5 days on Malt Extract Broth (MEB, Difco, Detroit, MI, USA) and incubated at $25{ }^{\circ} \mathrm{C}$ and $250 \mathrm{rpm}$ for $336 \mathrm{~h}$. Samples for chitinolytic activities were withdrawn daily. All media were autoclaved at $121^{\circ} \mathrm{C}$.

\subsection{Optimization of Growth Conditions of $\mathrm{pH}$, Temperature and Salinity}

The selected strains were tested in for their optimal growth at different $\mathrm{pH}$ (range 3.5-10.5, steps of $0.5 \mathrm{pH}$ ), temperatures (range $5-40{ }^{\circ} \mathrm{C}$, steps of $0.5^{\circ} \mathrm{C}$ ) and salinity (range $0-180 \%$, steps of $20 \%$; tests were also carried out at $38 \%$, the sea salinity recorded at the sampling site) on MEA plates modified to adjust $\mathrm{pH}$ and salinity. For each strain $\mathrm{pH}$ optimization was carried at $25{ }^{\circ} \mathrm{C}$ and $38 \%$ marine salt; temperature optimized at optimal $\mathrm{pH}$ and 3.8\%o marine salt, while salinity was optimized at optimal $\mathrm{pH}$ and temperature. 


\subsection{Optimization of Culture Medium by RSM Factorial Design}

Effect of the combined action of Corn Step Liquor (CSL, Sigma-Aldrich, St. Louis, MO USA) and YNB on the production and productivity of chitinolytic activity was optimised by a D-optimal design, with the following independent variables (factors):

$$
\begin{aligned}
& \mathrm{X}_{1}=\mathrm{CSL}(\mathrm{g} / \mathrm{L}) \\
& \mathrm{X}_{2}=\mathrm{YNB}(\mathrm{g} / \mathrm{L})
\end{aligned}
$$

The above dimensional independent variables were coded as dimensionless terms by the following equation:

$$
\mathrm{X}_{i}=\left(\mathrm{A}_{i}-\mathrm{A}_{0}\right) / \Delta \mathrm{A} \quad i=1,2
$$

where $X_{i}$ is a coded value and $A_{i}$ is the actual value of the variable, $\mathrm{A}_{0}$ is the actual value of the same variable at the centre point and $\Delta \mathrm{A}$ is the variable step change.

The range of the variables is given in Table 3.

Table 3. Experimental setup combining different concentration of CSL and YNB as suggested by the model.

\begin{tabular}{ccc}
\hline Experiment & CSL (\%) & YNB (\%) \\
\hline N1, N12 & 0 & 0 \\
N2, N13 & 0.5 & 0 \\
N3, N14 & 0 & 0.5 \\
N4, N15 & 0.5 & 0.5 \\
N5, N16 & 0 & 0.25 \\
N6, N17 & 0.5 & 0.25 \\
N7, N18 & 0.25 & 0 \\
N8, N19 & 0.25 & 0.5 \\
N9, N10, N11 & 0.25 & 0.25 \\
\hline
\end{tabular}

Data were subjected to analysis of variance (ANOVA) and fitted according to a second-order polynomial model shown by:

$$
Y=\beta o+\sum \beta_{\mathrm{i}} X_{\mathrm{i}}+\sum \beta_{\mathrm{ii}} X_{\mathrm{i}}^{2}+\sum \beta_{\mathrm{ij}} X_{\mathrm{i}} X_{\mathrm{j}}
$$

where $Y$ is the predicted response variable, $\beta$ o is the intercept, $\beta i$ and $\beta$ ii are the linear coefficient and quadratic coefficient, respectively, $\beta \mathrm{ij}$ is the interaction coefficient and $\mathrm{Xi}$ and $\mathrm{Xj}$ are the coded forms of the input variables. To estimate the impact of single independent variables on the response, regardless of the presence of the other factors, main effects were calculated using:

$$
Y=\beta o+\beta_{\mathrm{i}} X_{\mathrm{i}}+\beta_{\mathrm{ii}} X_{\mathrm{i}}^{2}
$$

Statistical examination of results and response surface study were carried out by the MODDE 5.0 software (Umetrics AB, Sweden).

Fermentations under optimal conditions for best enzyme production, as suggested by the model, were carried out in triplicate in subsequent experiments. All media for the RSM optimization were inoculated as mentioned above.

\subsection{Analytical Methods}

For the secondary screening and RSM optimization the overall chitinolytic activity was determined by the method of dinitrosalicylic acid (DNSA), using N-Acetyl-D-glucosamine for standard curve, as previously reported $[40,41]$. 
Under the assay conditions, one unit (U) of enzyme activity was defined as the amount of enzyme which released $1 \mu \mathrm{mol}$ per $\mathrm{mL}$ per min.

\section{Conclusions}

Clonostachys rosea IG119 was able to release high levels of chitinolytic enzymes under halophilic conditions. The results of this study indicate that this marine fungus could be considered as a new promising organism for possible applications in biotechnology. The RSM optimization allowed the increase of $C$. rosea enzyme activity (circa 1.53-fold enhancement) to levels suitable for possible industrial production. This work supplied the first demonstration that this fungal species also contains strains specifically adapted to the marine environment. In addition, it was the first study reporting high chitinolytic enzymes production by a marine strain of $C$. rosea.

Author Contributions: M.P., conceptualization, methodology, validation, investigation, resources, data curation, writing, supervision, project administration. P.B., conceptualization, methodology, validation, investigation, data curation, writing, software, visualization. V.G., methodology, validation, investigation, data curation, writing. M.F., conceptualization, methodology, validation, investigation, resources, data curation, writing, supervision, project administration.

Acknowledgments: Authors wish to thanks Claudia Di Giuseppe and Gian Maria Vettore, International Diving, Giglio Island, Italy and Domenico Battistello for their kind support during sampling.

Conflicts of Interest: The authors declare no conflict of interest.

\section{References}

1. Fenice, M.; Gallo, A.M.; Juarez-Jimenez, B.; Gonzalez-Lopez, J. Screening for extracellular enzyme activities by bacteria isolated from samples collected in the Tyrrhenian Sea. Ann. Microbiol. 2007, 57, 93-99. [CrossRef]

2. Trincone, A. Marine biocatalysts: enzymatic features and applications. Mar. Drugs 2011, 9, 478-499. [CrossRef] [PubMed]

3. Bonugli-Santos, R.C.; Dos Santos Vasconcelos, M.R.; Passarini, M.R.; Vieira, G.A.; Lopes, V.C.; Mainardi, P.H.; Feitosa, V.A. Marine-derived fungi: diversity of enzymes and biotechnological applications. Front. Microbiol. 2015, 6, 1-15. [CrossRef] [PubMed]

4. Srivastava, A.; Srivastava, M. Enzymes Market Type (Protease, Carbohydrase, Lipase, Polymerase and Nuclease, and Other Types), Source (Microorganisms, Plants, and Animals), Reaction Type (Hydrolase, Oxidoreductase, Transferase, Lyase, and Other Reaction Types), and Application (Food and Beverages, Household Care, Bioenergy, Pharmaceutical and Biotechnology, Feed, and Other Applications)—Global Opportunity Analysis and Industry Forecast, 2017-2024. 2018. Available online: https://www.alliedmarketresearch.com/enzymes-market (accessed on May 2018).

5. Alma'abadi, A.D.; Gojobori, T.; Mineta, K. Marine metagenome as a resource for novel enzymes. Genom. Proteom. Bioinform. 2015, 13, 290-295.

6. Debashish, G.; Malay, S.; Barindra, S.; Joydeep, M. Marine Enzymes. In Marine Biotechnology I. Advances in Biochemical Engineering/Biotechnology; Ulber, R., Le Gal, Y., Eds.; Springer: Heidelberg/Berlin, Germany, 2005.

7. Atalla, M.M.; Zeinab, H.K.; Eman, R.H.; Amani, A.Y.; Abeer, A.A.E.A. Screening of some marine-derived fungal isolates for lignin degrading enzymes (LDEs) production. Agric. Biol. J. N. Am. 2010, 1, 591-599.

8. Thirunavukkarasu, N.; Jahnes, B.; Broadstock, A.; Rajulu, M.G.; Murali, T.S.; Gopalan, V.; Suryanarayanan, T.S. Screening marine-derived endophytic fungi for xylan-degrading enzymes. Curr. Sci. 2015, 112-120.

9. Fenice, M. The psychrotolerant Antarctic fungus Lecanicillium muscarium CCFEE 5003: A powerful producer of cold-tolerant chitinolytic enzymes. Molecules 2016, 21, 447. [CrossRef]

10. Poulicek, M.; Machiroux, R.; Toussaint, C. Chitin diagenesis in deep-water sediments. In Chitin in Nature and Technology; Springer: Boston, MA, USA, 1986; pp. 523-530.

11. Keyhani, N.O.; Roseman, S. Physiological aspects of chitin catabolism in marine bacteria. Biochim. Biophys. Acta Gen. Subj. 1999, 1473, 108-122. [CrossRef]

12. Souza, C.P.; Almeida, B.C.; Colwell, R.R.; Rivera, I.N. The importance of chitin in the marine environment. Mar. Biotechnol. 2011, 13, 823-830. [CrossRef] 
13. Clipson, N.; Otte, M.; Landy, E. Biogeochemical roles of fungi in marine and estuarine habitats. In Fungi in Biogeochemical Cycles; Gadd, Ed.; Cambridge University Press: Cambridge, UK, 2006; pp. 436-446.

14. Barghini, P.; Moscatelli, D.; Garzillo, A.M.V.; Crognale, S.; Fenice, M. High production of cold-tolerant chitinases on shrimp wastes in bench-top bioreactor by the Antarctic fungus. Lecanicillium muscarium CCFEE 5003: Bioprocess optimization and characterization of two main enzymes. Enzyme Microb. Technol. 2013, 53, 331-338. [CrossRef]

15. Felse, P.A.; Panda, T. Production of microbial chitinases. A revisit. Bioprocess. Eng. 2000, 23, 127-134. [CrossRef]

16. Binod, P.; Sandhya, C.; Suma, P.; Szakacs, G.; Pandey, A. Fungal biosynthesis of endochitinase and chitobiase in solid state fermentation and their application for the production of $\mathrm{N}$-acetyl-d-glucosamine from colloidal chitin. Bioresour. Technol. 2007, 98, 2742-2748. [CrossRef]

17. Rocha-Pino, Z.; Vigueras, G.; Shirai, K. Production and activities of chitinases and hydrophobins from Lecanicillium lecanii. Bioproc. Biosyst. Eng. 2011, 34, 681-686. [CrossRef]

18. Fenice, M.; Di Giambattista, R.; Leuba, J.L.; Federici, F. Inactivation of Mucor plumbeus by the combined action of chitinase and high hydrostatic pressure. Int. J. Food Microbiol. 1999, 52, 109-113. [CrossRef]

19. Barghini, P.; Esti, M.; Pasqualetti, M.; Silvi, S.; Aquilanti, A.; Fenice, M. Crude cell wall degrading enzymes, by the Antarctic fungus Lecanicillium muscarium CCFEE 5003, inhibits the Ochratoxin-A producer Aspergillus carbonarius on white and red grapes. J. Environ. Prot. Ecol. 2013, 14, 1673-1679.

20. Fenice, M.; Selbmann, L.; Di Giambattista, R.; Federici, F. Chitinolytic activity at low temperature of an Antarctic strain (A3) of Verticillium cfr. lecanii. Res. Microbiol. 1998, 149, 289-300. [CrossRef]

21. Antal, Z.; Manczinger, L.; Szakacs, G.; Tengerdy, R.P.; Ferenczy, L. Colony growth, in vitro antagonism and secretion of extracellular enzymes in cold-tolerant strains of Trichoderma species. Mycol. Res. 2000, 104, 545-549. [CrossRef]

22. Juarez-Jimenez, B.; Rodelas, B.; Martinez-Toledo, M.V.; Gonzalez-Lopez, J.; Crognale, S.; Gallo, A.M.; Pesciaroli, C.; Fenice, M. Production of chitinolytic enzymes by a strain (BM17) of Paenibacillus pabuli isolated from crab shells samples collected in the East Sector of Central Tyrrhenian Sea. Int. J. Biol. Macr. 2008, 43, 27-31. [CrossRef]

23. Delgado-García, M.; Valdivia-Urdiales, B.; Aguilar-González, C.N.; Contreras-Esquivel, J.C.; Rodríguez-Herrera, R. Halophilic hydrolases as a new tool for the biotechnological industries. J. Sci. Food Agric. 2012, 92, 2575-2580. [CrossRef]

24. Chung, D.; Baek, K.; Bae, S.S.; Jung, J. Identification and characterization of a marine-derived chitinolytic fungus, Acremonium sp. YS2-2. J. Microbiol. 2019, 57, 372-380. [CrossRef]

25. Enache, M.; Kamekura, M. Hydrolytic enzymes of halophilic microorganisms and their economic values. Rom. J. Biochem. 2010, 47, 47-59.

26. Yin, J.; Chen, J.C.; Wu, Q.; Chen, G.Q. (2015). Halophiles, coming stars for industrial biotechnology. Biotechnol. Adv. 2015, 33, 1433-1442. [CrossRef]

27. Beygmoradi, A.; Homaei, A.; Hemmati, R.; Santos-Moriano, P.; Hormigo, D.; Fernández-Lucas, J. Marine chitinolytic enzymes, a biotechnological treasure hidden in the ocean? Appl. Microbiol. Biotechnol. 2018, 102, 9937-9948. [CrossRef]

28. Domsch, K.H.; Gams, W.; Anderson, T. Compendium of Soil Fungi, 2nd ed.; IHW-Verlag: Eching, Germany, 2007.

29. Chaverri, P.; Branco-Rocha, F.; Jaklitsch, W.; Gazis, R.; Degenkolb, T.; Samuels, G.J. Systematics of the Trichoderma harzianum species complex and the re-identification of commercial biocontrol strains. Mycologia 2015, 10, 558-590. [CrossRef]

30. Saravanakumar, K.; Kathiresan, K.; Chen, J. Marine Fungal Genomics: Trichoderma. In Marine OMICS Principles and Applications; Kim, S.K., Ed.; CRC Press: London, UK, 2016; pp. 79-104.

31. Touati, I.; Ruiz, N.; Thomas, O.; Druzhinina, I.S.; Atanasova, L.; Tabbene, O.; Elkahoui, S.; Benzekri, R.; Bouslama, L.; Pouchus, Y.F.; Limam, F. Hyporientalin A, an anti-Candida peptaibol from a marine Trichoderma orientale. World J. Microbiol. Biotechnol. 2018, 34, 98. [CrossRef]

32. Mamarabadi, M.; Jensen, B.; Lübeck, M. Three endochitinase-encoding genes identified in the biocontrol fungus Clonostachys rosea are differentially expressed. Curr. Genet. 2008, 54, 57. [CrossRef]

33. Zheng, Y.; Wang, X.; Liu, S.; Zhang, K.; Cai, Z.; Chen, X.; Zhang, Y.; Liu, J.; Wang, A. The Endochitinase of Clonostachys rosea Enhances the Biocontrol Efficiency of Bacillus amyloliquefaciens by Increasing Its Activities of Defense Enzymes. Int. J. Mol. Sci. 2018, 19, 2221. 
34. Dias, A.; Ruiz, N.; Couzinet-Mossion, A.; Bertrand, S.; Duflos, M.; Pouchus, Y.F.; Barnathan, G.; Nazih, H.; Wielgosz-Collin, G. The marine-derived fungus Clonostachys rosea, source of a rare conjugated 4-Me-6E, 8E-hexadecadienoic acid reducing viability of MCF-7 breast cancer cells and gene expression of lipogenic enzymes. Mar. Drugs 2015, 13, 4934-4948. [CrossRef]

35. Fenice, M.; Barghini, P.; Selbmann, L.; Federici, F. Combined effects of agitation and aeration on the chitinolytic enzymes production by the Antarctic fungus Lecanicillium muscarium CCFEE 5003. Microb. Cell Fact. 2012, 11, 12. [CrossRef]

36. Hull, S.R.; Yang, B.Y.; Venzke, D.; Kulhavy, K.; Montgomery, R. Composition of corn steep water during steeping. J. Agric. Food Chem. 1996, 44, 1857-1863. [CrossRef]

37. Maddipati, P.; Atiyeh, H.K.; Bellmer, D.D.; Huhnke, R.L. Ethanol production from syngas by Clostridium strain P11 using corn steep liquor as a nutrient replacement to yeast extract. Bioresour. Technol. 2011, 102, 6494-6501. [CrossRef]

38. Daniels, R.S. Corn Steep Liquor as A Biostimulant Composition. U.S. Patent No. 8568758 B2. Available online: http://www.freepatentsonline.com/y2012/0028801.html (accessed on 29 October 2013).

39. De la Cruz, J.; Hidalgo-Gallego, A.; Lora, J.M.; Benitez, T.; Pintor-Toro, J.A.; Llobell, A. Isolation and characterization of three chitinases from Trichoderma harzianum. Eur. J. Biochem. 1992, 859-867. [CrossRef]

40. Fenice, M.; Leuba, J.L.; Federici, F. Chitinolytic enzyme activity of Penicillium janthinellum P9 in bench-top bioreactor. J. Ferment. Bioeng. 1998, 86, 620-623. [CrossRef]

41. Fenice, M.; Di Giambattista, R.; Raetz, E.; Leuba, J.L.; Federici, F. Repeated-batch and continuous production of chitinolytic enzymes by Penicillium janthinellum immobilised on chemically-modified macroporous cellulose. J. Biotechnol. 1998, 62, 119-131. [CrossRef]

42. Kumar, M.; Brar, A.; Vivekanand, V.; Pareek, N. Production of chitinase from thermophilic Humicola grisea and its application in production of bioactive chitooligosaccharides. Int. J. Biol. Macromol. 2017, 104, 1641-1647. [CrossRef]

43. Braga, F.R.; Soares, F.E.F.; Giuberti, T.Z.; Lopes, A.D.C.G.; Lacerda, T.; de Hollanda Ayupe, T.; Queiroz, P.V.; de Souza Gouveia, A.; Pinheiro, L.; Araujo, A.L.; et al. Nematocidal activity of extracellular enzymes produced by the nematophagous fungus Duddingtonia flagrans on cyathostomin infective larvae. Vet. Parasitol. 2015, 212, 214-218. [CrossRef]

44. Panno, L.; Bruno, M.; Voyron, S.; Anastasi, A.; Gnavi, G.; Miserere, L.; Varese, G.C. Diversity, ecological role and potential biotechnological applications of marine fungi associated to the seagrass Posidonia Oceanicirca. New Biotechnol. 2013, 30, 685-694. [CrossRef]

45. Ellis, M.B. Dematiaceous Hyphomycete; Commonwealth Mycological Institute: Kew, UK, 1971.

46. Ellis, M.B. More Dematiaceous Hyphomycetes; Commonwealth Mycological Institute: Kew, UK, 1976.

47. Kohlmeyer, J.; Kohlmeyer, E. Marine Mycology: The Higher Fungi; Academic Press: New York, NY, USA, 1979.

48. Pitt, J.I. The genus Penicillium and its teleomorphic states Eupenicillium and Talaromyces; Academic Press Inc.: London, UK, 1979.

49. Sutton, B.C. The Coelomycetes Fungi Imperfecti with Pycenidia, Acervuli and Stromata; Commonwealth Mycological Institute: Kew, UK, 1980.

50. Klich, M.A. Identification of Common Aspergillus Species, 1st ed.; CBS: Utrecht, The Netherlands, 2002.

51. White, T.J.; Bruns, T.; Lee, S.; Taylor, J. Amplification and direct sequencing of fungal ribosomal RNA genes for phylogenetics. In PCR Protocols a Guide to Methods and Applications; Innis, M.A., Gelfand, D.H., Sninsky, J.J., White, T.J., Eds.; Academic Press: New York, NY, USA, 1990; pp. 315-322.

52. Carbone, I.; Kohn, L.M. A method for designing primer sets for speciation studies in filamentous ascomycetes. Mycologia 1999, 91, 553-556. [CrossRef]

Sample Availability: Samples of the microbial strains are available from the authors. 